Original article

DOI: $10.19027 /$ jai.20.1.82-92

\title{
Production performance and nitrogen and phosphorus mass balance in biofloc-based African catfish intensive culture at different densities
}

\section{Kinerja produksi dan keseimbangan massa nitrogen dan fosfor dalam budidaya ikan lele intensif berbasis bioflok pada kepadatan berbeda}

\author{
Sumitro $^{12}$, Tatag Budiardi ${ }^{1}$, Hilmi Fauzi ${ }^{1}$, Julie Ekasari ${ }^{1 *}$ \\ 'Department of Aquaculture, Faculty of Fisheries and Marine Sciences, IPB University, Indonesia \\ ${ }^{2}$ Program Studi Budidaya Perairan Fakultas perikanan dan Ilmu Kelautan Universitas Dayanu Ikhsanuddin, \\ Indonesia \\ *Corresponding author: j_ekasari@apps.ipb.ac.id
}

(Received June 21, 2020; Accepted November 19, 2020)

\begin{abstract}
This study aimed to evaluate the production performance and nitrogen and phosphorus mass balance of bioflocbased intensive African catfish Clarias gariepinus culture at different densities. African catfish with an average body weight of $2.64 \pm 0.06 \mathrm{~g}$ was randomly distributed into 12 units of round tank with a working volume of $2 \mathrm{~m}^{3}$ of water and maintained for 8 weeks. A completely randomized experimental design with four treatments (in triplicates), i.e. a control treatment at a fish density of $500 \mathrm{fish} / \mathrm{m}^{3}$ with regular water exchange and without organic carbon source addition, and biofloc treatments (BFT) at three different densities, i.e. $500 \mathrm{fish} / \mathrm{m}^{3}$ (BFT500), $750 \mathrm{fish} / \mathrm{m}^{3}$ (BFT750), and $1000 \mathrm{fish} / \mathrm{m}^{3}$ (BFT1000). Biofloc systems were performed with a regular addition of tapioca flour $(40 \% \mathrm{C})$. The production performance between biofloc system and the control was not significantly different, however water and nitrogen utilizations were significantly more efficient in biofloc system than those of the control. The highest fish specific growth rate was observed in BFT1000 and BFT500 (6.01\%/day and $5.96 \% /$ day, respectively $)(\mathrm{P}<0.05)$. Fish density significantly affected the fish growth performance and productivity in biofloc systems, but not nitrogen and phosphorus utilizations. In conclusion, higher fish density significantly increased the production and water utilization efficiency in biofloc systems, but has no effect on nitrogen and phosphorus utilization efficiency. Furthermore, increasing the fish density could significantly reduce the fish survival andrequire more efforts to control biofloc biomass in the culture system.
\end{abstract}

Keywords: biofloc, density, production performance, nitrogen, phosphorus, African catfish

\begin{abstract}
ABSTRAK
Penelitian ini bertujuan mengevaluasi kinerja produksi dan keseimbangan massa nitrogen dan fosfor dalam budidaya ikan lele intensif berbasis bioflok pada kepadatan berbeda. Ikan lele dengan berat tubuh 2,64 $\pm 0,06 \mathrm{~g}$ secara acak didistribusikan pada 12 unit bak bundar dengan volume air sebesar $2 \mathrm{~m}^{3}$ dan dipelihara selama 8 minggu. Penelitian ini menggunakan rancangan acak lengkap dengan empat perlakuan dan tiga ulangan, yaitu padat tebar 500 ekor $\mathrm{ikan} / \mathrm{m}^{3}$ sebagai kontrol dengan pergantian air dan tanpa penambahan sumber karbon, sedangkan perlakuan sistem bioflok (BFT) dengan kepadatan yang berbeda, yaitu $500 \mathrm{ikan} / \mathrm{m}^{3}$ (BFT500), $750 \mathrm{ikan} / \mathrm{m}^{3}$ (BFT750), dan 1000 $\mathrm{ikan} / \mathrm{m}^{3}$ (BFT1000). Penambahan karbon pada sistem bioflok menggunakan tapioka dengan kadar karbon sebesar 40\%. Kinerja produksi tidak berbeda nyata antara sistem bioflok dan kontrol, namun pada sistem bioflok lebih efisien dalam penggunaan air dan pemanfaatan nitrogen dibandingkan kontrol. Laju pertumbuhan harian tertinggi terdapat pada BFT1000 dan BFT500, masing-masing $(6.01 \% /$ hari dan 5.96\%/hari) $(\mathrm{P}<0.05)$. Padat tebar secara signifikan memengaruhi pertumbuhan dan produktivitas ikan dalam system bioflok, tetapi tidak memengaruhi pemanfaatan nitrogen dan fosfor. Kesimpulannya, semakin tinggi kepadatan ikan, secara signifikan meningkatkan produksi ikan dan lebih efisien dalam hal penggunaan air dalam system bioflok, tetapi tidak berpengaruh terhadap efisiensi pemanfaatan nitrogen dan fosfor. Selain itu, peningkatan kepadatan ikan dapat menurunkan kelangsungan hidup ikan secara signifikan dan memerlukan lebih banyak upaya untuk mengendalikan biomassa bioflok dalam system budidaya.
\end{abstract}

Kata kunci: bioflok, kepadatan, kinerja produksi, nitrogen, fosfor, ikan lele. 


\section{INTRODUCTION}

The increasing demand of aquaculture product is not accompanied by the increase of space and good quality water. This limited resource has forced aquaculture industry toward intensification (Diana et al., 2013; Aubin et al., 2019). At one hand, intensification could improve the productivity, i.e. the fish production per unit of space or water. On the other hand, intensification brings about adverse effects on the water quality of the culture medium, increase water utilization and nutrient waste into the environment. The high density of fish applied in an intensive aquaculture system requires more feed loading into the system and consequently more wasteis generated (Little $\&$ Bunting, 2016). The waste coming from unconsumed feed and undigested feed materials (faeces) accumulate as organic matter, whereas metabolic waste from the cultured organisms enters the water in dissolved forms (Herath \& Satoh, 2015). Some the most common nutrient waste in an aquaculture system are nitrogenous and phosphorus (Rijn, 2013; Fourooghifard et al., 2018; Dauda et al., 2019). Nitrogenous waste such as ammonia and nitrite are toxic for most aquatic organism even at low concentrations (Zhang et al., 2012; Wang et al., 2017; Li et al., 2020). Although rarely considered as toxic compounds, Phosphorus waste from aquaculture units has been considered to contribute to the eutrophication of natural aquatic environment (Herath \& Satoh, 2015; Nikolai \& Dzialowski, 2014). The increase of production through aquaculture intensification should apply aquaculture technology that can generate minimum negative impacts to the environment (Aubin et al., 2019).

One of the technologies that have been developed to increase aquaculture productivity with minimum negative impact on culture media is biofloc technology. The main principle of this technology is the utilization of ammonia nitrogen to synthesize microbial protein that maybe consumed by the cultured animals as a supplemental feed for fish (Avnimelech, 1999). The biofloc system is considered to be environmental friendly because of the nutrient recycling mechanism (Emerenciano et al., 2013; Bossier \& Ekasari, 2017). This process will occur in the presence of balanced carbon/nitrogen in the water. The microbial biomass generated in this system could form a micro-aggregate, commonly known as biofloc, that consists of various microorganisms in aquatic environment, including various types of bacteria, microalgae, zooplankton, annelids, as well as particulate matters that trapped in biofloc matrix (MonroyDosta et al., 2015; Germán et al., 2018). As bioflocs mainly contains living microorganisms, suspended bioflocs can be utilized by the cultured organisms as a food source (Crab et al., 2012; Poliet al., 2015)

African catfish Clarias gariepinus is highly tolerance to low water quality and can be cultured at high density. It has been considered that $C$. gariepinusis a potential fish to be cultured in biofloc systems (Bakar et al., 2015; Fauji et al., 2018; Romano et al., 2018; Dauda et al., 2017). The increase of fish biomass in biofloc system consequently increases feed loading and nutrient waste, as well as the microbial activity. Although limited information is available, it may be hypothesized that fish density may also alter bioflocs biological and physico-chemical characteristics, that leads to variation in water quality and nutrient mass balance in the culture system. The present study aimed to evaluate the production performance and nitrogen and phosphorus mass balance in biofloc-based intensive African catfish culture at different densities.

\section{MATERIALS AND METHODS}

The experiment applied a completely randomized experimental design, consisting of four treatments in triplicates, i.e.:

Control $500 \quad$ : regular water exchange at a fish density of $500 \mathrm{fish} / \mathrm{m}^{3}$

BFT $500 \quad$ : biofloc system at a fish density of $500 \mathrm{fish} / \mathrm{m}^{3}$

BFT 750 : biofloc system at a fish densityof $750 \mathrm{fish} / \mathrm{m}^{3}$

BFT 1000 : biofloc system at a fish density of $1000 \mathrm{fish} / \mathrm{m}^{3}$

\section{Fish maintenance}

Fish culture was done in 12 units of round tank made of wire mesh frame $(7 \mathrm{~mm})$ at a diameter of $2 \mathrm{~m}$ and height of $120 \mathrm{~cm}$ with a plastic lining located at Amanah Fish Farm, Bogor, Indonesia. Each tank was filled with chlorinated freshwater to a final working volume of $2 \mathrm{~m}^{3}$. Biofloc growth was stimulated by adding a commercial probiotic (Sanolife ${ }^{\circledR}$ INVE, Belgium) (Hostin et al., 2017) at a concentration of $1 \mathrm{mg} / \mathrm{L}, 10 \mathrm{mg} / \mathrm{L}$ ammonium chloride and $65 \mathrm{mg} / \mathrm{L}$ tapioca flour ( $40 \%$ organic $\mathrm{C}$ ) with an estimated $\mathrm{C} / \mathrm{N}$ ratio of 
10. Biofloc growth stimulation was done for 7 days under strong aeration until bioflocs particle was observed and no total ammoniacal nitrogen (TAN) was detected. Maintaining of biofloc during the culture period was done by the addition of tapioca flour at a level of $3 \%$ of the total feed.

Visually healthy African catfish juveniles were obtained from a local hatchery in Bogor, West Java, Indonesia with an initial body length and body weight of $6.04 \pm 0.08 \mathrm{~cm}$ and $2.64 \pm 0.06$ $\mathrm{g}$. The fish was maintained for 8 weeks and fed to satiation with a commercial feed (protein content of $34 \%$ ) three times daily. Water quality in the control treatment was maintained by regular water exchange at about $20-30 \%$ every 3-4 days. There was no water replacement in biofloc systems, but fresh water was added occasionally to replace the water loss due to evaporation. Floc volume was maintained at a level of less than $80 \mathrm{~mL} / \mathrm{L}$ by regularly removal of bioflocs every $2-3$ days for the first 4 weeks of culture and everyday afterward. Liming was done at a concentration of $10 \mathrm{mg} / \mathrm{L}$ at day 10 to stimulate microbial aggregation. Fish sampling was done every 14 days to monitor the growth of the fish. At the initial and the end of the experiment, some fish samples were taken and kept in a $-20^{\circ} \mathrm{C}$ freezer until further analyses.

\section{Zootechnical parameters}

Zootechnical parameters observed in this experiment included fish survival, specific growth rate, final biomass, feed quantity, food conversion ratio and protein retention. Fish survival was determined as the proportion of alive fish at the end of the experiment of the fish initial number. Specific growth rate was calculated according to the following equation Huisman (1987):

$$
\operatorname{SGR}(\% / \text { day })=\left[\sqrt[t]{\frac{\mathrm{Wt}}{\mathrm{Wo}_{\mathrm{o}}}}-1\right] \times 100
$$

With $\mathrm{SGR}=$ specific growth rate (\%/day), $\mathrm{W}_{\mathrm{t}}=$ final average body weight $(\mathrm{g}), \mathrm{W}_{0}=$ initial average body weight $(\mathrm{g})$, and $\mathrm{t}=$ culture period (days). Feed conversion ratio was calculated as the ratio between the total feed given to the fish and the fish biomass gain. Protein retention was calculated as the proportion of the gained protein in fish biomass relative to the feed protein intake (Watanabe 1988).

\section{Water quality parameters}

Water quality parameters such as temperature, $\mathrm{pH}$ and dissolved oxygen concentrations were measured in situ using $\mathrm{pH}$ meter (Hanna Instrument) and DO meter (Lutron DO5519). Dissolved inorganic nitrogen (DIN) was calculated as the sum of TAN, nitrite and nitrate concentrations. Floc volume, temperature and pHwere measured daily, whereas DO was measured every three days. Dissolved organic nitrogen (DON) was measured at the end of the experiment, whereas total ammoniacal nitrogen (TAN), nitrite, nitrate, total phosphorous (TP), total suspended solids (TSS) and alkalinity were measured every 14 days with the procedures following APHA (1998).

\section{Nitrogen and phosphorus mass balance}

Nitrogen and phosphorus content in fish, feed, tapioca and total suspended solids was determined by Kjeldahl method and AOAC (1995), respectively. Nitrogen and phosphorus output from the discharged water were estimated according to the volume of the discharged water and the concentration of DIN, DON and total phosphorus in the discharged water, and the nitrogen content of the total suspended solids. Unaccounted $\mathrm{N}$ and $\mathrm{P}$ were estimated by subtracting the total N/P input with the total N/P output. Nitrogen and phosphorus utilization efficiency was calculated according to the proportion of $\mathrm{N}$ and $\mathrm{P}$ in the harvested fish relative to the total nutrient input.

\section{Statistical analysis}

Production performance data (feed consumption, final weight, final biomass, survival rate, specific growth rate, feed conversion ratio, protein retention, productivity, and water used) and nitrogen and phosphorus mass balanced were statistically analyzed using Microsoft Excel 2008 and StatPlus version 2009. Water quality was analyzed descriptively. Analysis of variance (ANOVA) with F test was conducted in $95 \%$ of confidence level. Duncan post hoc test would be arranged to determine the significant difference amongst treatments. Data homogeneity and normality were tested using Levene's test and Kolmogorov-Smirnov. Arcsine transformation would be done when data variance was found.

\section{RESULTS AND DISCUSSION}

\section{Results}

\section{Fish production performance}

Fish final weight were higher in biofloc treatments than that of the control, regardless the fish density (Table 1). The highest fish final 
weight was observed in treatment BFT1000. Similarly, specific growth rates of the fish were higher in biofloc treatments compared to that of the control. Fish survival in BFT500 was not significantly different from the control at the same fish density. Lower survival, however, were observed at higher fish density (BFT750 and BFT1000). Regardless the lower fish survival, BFT1000 demonstrated the highest biomass and productivity. Feed quantity was not different between the control and biofloc system at the same density, however it was higher when the

Table 1. African catfish production performance of in biofloc-based culture at different densities (500, 750, and $1000 \mathrm{fish} / \mathrm{m}^{3}$ ) and the control during 8 weeks of culture period.

\begin{tabular}{lcccc}
\hline & Control 500 & BFT500 & BFT750 & BFT1000 \\
\hline Initial weight $(\mathrm{g})$ & $2.66 \pm 0.03^{\mathrm{a}}$ & $2.63 \pm 0.06^{\mathrm{a}}$ & $2.67 \pm 0.04^{\mathrm{a}}$ & $2.61 \pm 0.10^{\mathrm{a}}$ \\
Feed quantity $(\mathrm{kg})$ & $45.67 \pm 1.56^{\mathrm{a}}$ & $41.33 \pm 4.16^{\mathrm{a}}$ & $61.33 \pm 5.67^{\mathrm{b}}$ & $71.67 \pm 4.93^{\mathrm{b}}$ \\
Final weight $(\mathrm{g})$ & $69.07 \pm 1.38^{\mathrm{c}}$ & $74.30 \pm 1.23^{\mathrm{ab}}$ & $72.30 \pm 0.2^{\mathrm{b}}$ & $75.71 \pm 1.6^{\mathrm{a}}$ \\
Final biomass $(\mathrm{kg})$ & $48.33 \pm 4.04^{\mathrm{c}}$ & $49.67 \pm 1.53^{\mathrm{c}}$ & $70.67 \pm 1.53^{\mathrm{b}}$ & $79.67 \pm 2.08^{\mathrm{a}}$ \\
Survival $(\%)$ & $78.60 \pm 8.25^{\mathrm{a}}$ & $75.87 \pm 2.18^{\mathrm{a}}$ & $74.27 \pm 3.29^{\mathrm{ab}}$ & $60.45 \pm 5.82^{\mathrm{b}}$ \\
SGR $(\% /$ day)* & $5.81 \pm 0.02^{\mathrm{c}}$ & $5.96 \pm 0.02^{\mathrm{a}}$ & $5.89 \pm 0.03^{\mathrm{b}}$ & $6.01 \pm 0.03^{\mathrm{a}}$ \\
\hline FCR $^{*}$ & $0.94 \pm 0.08^{\mathrm{a}}$ & $0.86 \pm 0.12^{\mathrm{a}}$ & $0.87 \pm 0.06^{\mathrm{a}}$ & $0.90 \pm 0.08^{\mathrm{a}}$ \\
\hline Protein retention $(\%)$ & $32.34 \pm 2.76^{\mathrm{b}}$ & $51.95 \pm 6.79^{\mathrm{a}}$ & $51.36 \pm 3.81^{\mathrm{a}}$ & $49.70 \pm 4.89^{\mathrm{a}}$ \\
Productivity $\left(\mathrm{kg} / \mathrm{m}^{3}\right)$ & $24.25 \pm 2.15^{\mathrm{a}}$ & $25.02 \pm 0.74^{\mathrm{a}}$ & $35.33 \pm 0.73^{\mathrm{b}}$ & $39.72 \pm 1.00^{\mathrm{c}}$ \\
Water utilization $\left(\mathrm{m}^{3} /\right.$ ton fish) & $102.35 \pm 11.95^{\mathrm{c}}$ & $63.33 \pm 2.04^{\mathrm{b}}$ & $49.43 \pm 1.48^{\mathrm{a}}$ & $48.86 \pm 1.84^{\mathrm{a}}$ \\
\hline
\end{tabular}

Mean values ( \pm standard deviation) followed by different superscript letters indicate significant differences $(\mathrm{P}<0.05) . * \mathrm{SGR}=$ specific growth rate, $\mathrm{FCR}=$ feed conversion ratio

Table 2. Nitrogen mass balance in biofloc-based C. gariepinus culture at different densities (500, 750, and 1000 $\mathrm{fish} / \mathrm{m}^{3}$ ) and a control during 8 weeks of culture period.

\begin{tabular}{lcccc}
\hline & Control 500 & BFT 500 & BFT 750 & BFT 1000 \\
\hline N input (g): & & & & \\
$\quad$ DIN in water & $1.88 \pm 0.04$ & $1.96 \pm 0.20$ & $2.07 \pm 0.26$ & $2.15 \pm 0.32$ \\
$\quad$ Initial fish & $37.9 \pm 0$ & $36 \pm 0$ & $56 \pm 0$ & $73 \pm 2$ \\
Feed & $2483 \pm 62$ & $2248 \pm 226$ & $3335 \pm 309$ & $3897 \pm 268$ \\
Tapioca & - & $1.19 \pm 0.13$ & $1.78 \pm 0.16$ & $2.08 \pm 0.15$ \\
Total input & $2523 \pm 63$ & $2288 \pm 226$ & $3395 \pm 310$ & $3975 \pm 268$ \\
N output (g): & & & & \\
Discharged water & & & & \\
DIN & $2.63 \pm 0.62$ & $1.16 \pm 0.04$ & $1.40 \pm 0.075$ & $1.88 \pm 0.09$ \\
DON & $2.49 \pm 0.62$ & $0.98 \pm 0.04$ & $1.17 \pm 0.12$ & $1.64 \pm 0.08$ \\
TSS & $13.10 \pm 1.20$ & $13.30 \pm 1.26$ & $23.36 \pm 1.94$ & $37.62 \pm 3.84$ \\
Harvest & & & & \\
DIN & $11.49 \pm 1.23$ & $11.80 \pm 0.44$ & $11.49 \pm 0.91$ & $12.22 \pm 0.77$ \\
DON & $11.34 \pm 1.23$ & $11.62 \pm 0.44$ & $11.26 \pm 0.93$ & $11.97 \pm 0.76$ \\
TSS & $8.20 \pm 1.91$ & $23.20 \pm 6.42$ & $34.00 \pm 6.25$ & $44.20 \pm 5.10$ \\
Fish & $840 \pm 46$ & $1188 \pm 35$ & $1768 \pm 48$ & $2003 \pm 44$ \\
Total output & $889 \pm 45^{\mathrm{d}}$ & $1250 \pm 37^{\mathrm{c}}$ & $1851 \pm 53^{\mathrm{b}}$ & $2113 \pm 44^{\mathrm{a}}$ \\
Uncounted N (g) & $1634 \pm 69^{\mathrm{b}}$ & $1038 \pm 246^{\mathrm{a}}$ & $1544 \pm 270^{\mathrm{ab}}$ & $1862 \pm 302^{\mathrm{b}}$ \\
Uncounted N(\%) & $64.76 \pm 1.86^{\mathrm{b}}$ & $44.97 \pm 6.30^{\mathrm{a}}$ & $45.24 \pm 4.12^{\mathrm{a}}$ & $46.64 \pm 4.66^{\mathrm{a}}$ \\
Efficiency $(\%)$ & $33.29 \pm 1.82^{\mathrm{b}}$ & $52.31 \pm 6.12^{\mathrm{a}}$ & $52.30 \pm 3.80^{\mathrm{a}}$ & $50.60 \pm 4.54^{\mathrm{a}}$ \\
\hline
\end{tabular}

Mean values ( \pm standard deviation) followed by different superscript letters indicate significant differences $(\mathrm{P}<0.05)$. *DIN=dissolved inorganic $\mathrm{N}, \mathrm{DON}=$ dissolved organic $\mathrm{N}, \mathrm{TSS}=$ total suspended solids 
fish density increased. Feed conversion ratio was not significantly different between the treatments. But protein retentions were significantly higher in biofloc treatments than that of the control. Water utilization in the control was significantly higher than those of biofloc systems. Biofloc systems with fish density of 750 and $1000 / \mathrm{m}^{3}$ demonstrated lower water utilization than that of biofloc system with a density of $500 / \mathrm{m}^{3}$.

\section{Water quality}

The trend of alkalinity in the culture medium were relatively similar in all treatments, except for treatment BF1000, where alkalinity concentrations were higher in week 4 and 6 (Figure 1). During the first two weeks, reductions in alkalinity were observed in all treatments, but subsequently increased afterward. All treatments showed relatively the same $\mathrm{pH}$ values, except for the control, which showed slightly lower $\mathrm{pH}$. Dissolved oxygen concentrations and temperature were in the range of $2-3 \mathrm{mg} / \mathrm{L}$ and $27-29^{\circ} \mathrm{C}$, respectively and there were no significant differences observed between the treatments. Total ammoniacal nitrogen, nitrite, nitrate and total dissolved inorganic nitrogen concentrations were relatively similar between the treatments during the experimental periods (Figure 2). Total suspended solids were strongly affected by the fish density and biofloc system. Biofloc systems demonstrated higher total suspended solids than that of the control and higher density of fish resulted in higher total suspended solids. Floc volume was relatively the same between biofloc systems, but floc volume index was significantly affected by the fish density, where higher fish density resulted in biofloc with higher settleability (Figure 3).

\section{Nitrogen and phosphorus mass balance}

Nitrogen and phosphorus mass balance in biofloc-based African catfish culture are presented in Table 2 and Table 3. Total input nitrogen and phosphorus were significantly affected by the fish density. Total harvested nitrogen and phosphorus was higher in biofloc system than that of the control, even at the same fish density. On the other hand, the proportion of unaccounted $\mathrm{N}$ and $\mathrm{P}$ were lower in biofloc system compared to that of the control at the same fish density (Figure 3 and Figure 4). Overall $\mathrm{N}$ and $\mathrm{P}$ utilization efficiencies were higher in biofloc systems compared to that of the control, regardless the fish density.

Table 3. Phosphorus mass balance in biofloc-based C. gariepinus culture at different densities (500, 750, and 1000 fish $/ \mathrm{m}^{3}$ ) and a control during 8 weeks of culture period.

\begin{tabular}{|c|c|c|c|c|}
\hline & Control 500 & BFT 500 & BFT 750 & BFT 1000 \\
\hline \multicolumn{5}{|l|}{ P input (g): } \\
\hline TP in water & $0.10 \pm 0.06$ & $0.10 \pm 0.03$ & $0.14 \pm 0.04$ & $0.13 \pm 0.02$ \\
\hline Initial fish & $11.59 \pm 0.14$ & $11.46 \pm 0.25$ & $17.40 \pm 0.27$ & $22.71 \pm 0.88$ \\
\hline Feed & $372 \pm 9$ & $337 \pm 34$ & $500 \pm 46$ & $584 \pm 40$ \\
\hline Tapioca & - & $0.31 \pm 0.04$ & $0.47 \pm 0.04$ & $0.55 \pm 0.04$ \\
\hline Total input & $384 \pm 9$ & $349 \pm 34$ & $518 \pm 47$ & $607 \pm 40$ \\
\hline \multicolumn{5}{|l|}{ P output $(\mathrm{g})$ : } \\
\hline \multicolumn{5}{|l|}{ Discharged water } \\
\hline TP in water & $0.15 \pm 0.10$ & $0.06 \pm 0.02$ & $0.11 \pm 0.03$ & $0.12 \pm 0.02$ \\
\hline TSS & $2.33 \pm 0.71$ & $1.99 \pm 0.28$ & $3.95 \pm 0.53$ & $8.35 \pm 1.35$ \\
\hline \multicolumn{5}{|l|}{ Harvest } \\
\hline TP in water & $4.46 \pm 1.30$ & $5.21 \pm 0.30$ & $5.45 \pm 0.78$ & $4.65 \pm 0.38$ \\
\hline TSS & $11.15 \pm 2.68$ & $27.17 \pm 2.16$ & $40.60 \pm 3.83$ & $67.18 \pm 9.11$ \\
\hline Harvested fish & $222 \pm 12$ & $244 \pm 23$ & $358 \pm 56$ & $395 \pm 55$ \\
\hline Total output & $240 \pm 10$ & $278 \pm 23$ & $408 \pm 51$ & $475 \pm 44$ \\
\hline Uncounted P (g) & $144 \pm 14$ & $70 \pm 13$ & $110 \pm 20$ & $132 \pm 84$ \\
\hline Uncounted P (\%) & $37 \pm 3$ & $20 \pm 2$ & $21 \pm 4$ & $21 \pm 13$ \\
\hline Efficiency $(\%)$ & $58 \pm 3$ & $70 \pm 2$ & $69 \pm 6$ & $66 \pm 14$ \\
\hline
\end{tabular}

Mean values ( \pm standard deviation) followed by different superscript letters indicate significant differences $(\mathrm{P}<0.05)$. *TP=total phosphorus, TSS=total suspended solids 


\section{Discussion}

Dissolved oxygen concentration in all treatments gradually decreased as the culture progressed. However, as African catfish can extracts oxygen directly from the atmosfer, it seems to have little effect on the fish growth (Palm et al., 2018). Total ammoniacal nitrogen, nitrite and nitrate concentrations were not significantly different between treatments. Similar concentrations of dissolved inorganic nitrogenous compounds between the treatments may indicate that microbial assimilation of ammonia/ammonium occurred in biofloc systems could maintain the levels of these compounds at an acceptable level and was comparable to the system with regular water exchange. Similar trend was also demonstrated by Bakar et al. (2015) who reported that the addition of organic carbon into biofloc-based African catfish culture could reduce ammonia concentration up to $98.7 \%$. Apart from heterotrophic nitrogen assimilation, nitrite and nitrate were also present in the culture medium, indicating the activity of nitrification bacteria in all biofloc systems regardless the fish density. It is important to note that the dissolved inorganic nitrogen in the present study was considerably low compared to that reported in other studies (Palm et al., 2018; Chen et al., 2020). Interestingly, there were significant reduction in nitrate concentrations in all treatments observed after the second week of culture. This reduction might relate to the activity of denitrification bacteria that convert nitrate into nitrite and nitrogen gas which likely to occur at low oxygen concentration (Strauch et al., 2018; Rajta et al., 2019). This confirms previous study by Chen et al. (2020) reporting that denitrification might be on going in African catfish biofloc system as indicated by the decrease in nitrate concentrations, the increase of alkalinity and the presence of some genera of bacteria that have the activity in denitrification.

Total suspended solids and floc volume were measured to represent the biofloc biomass in the culture systems. Total suspended solids were increasing remarkably with the increase of fish density. High biofloc accumulation in a fish culture system may negatively affect the culture, as it will increase the microbial consumption of oxygen and the risk of gill occlusion in the fish (Kjelland et al., 2015; Chen et al., 2020). In this regard, the present study applied biofloc biomass control by regular discharge of biofloc suspension to obtain a maximum level of floc volume at 80 $\mathrm{mL} / \mathrm{L}$. Floc volume was chosen as an indicator for biofloc biomass based on previous experience and also the practicality in the field.However, TSS and FV data in the present study demonstrated that floc volume may not always linearly correspond to the total suspended solids. Biofloc volume in treatments BFT750 and BFT1000 were relatively similar to that of BFT500, however these treatments clearly showed increasing TSS with
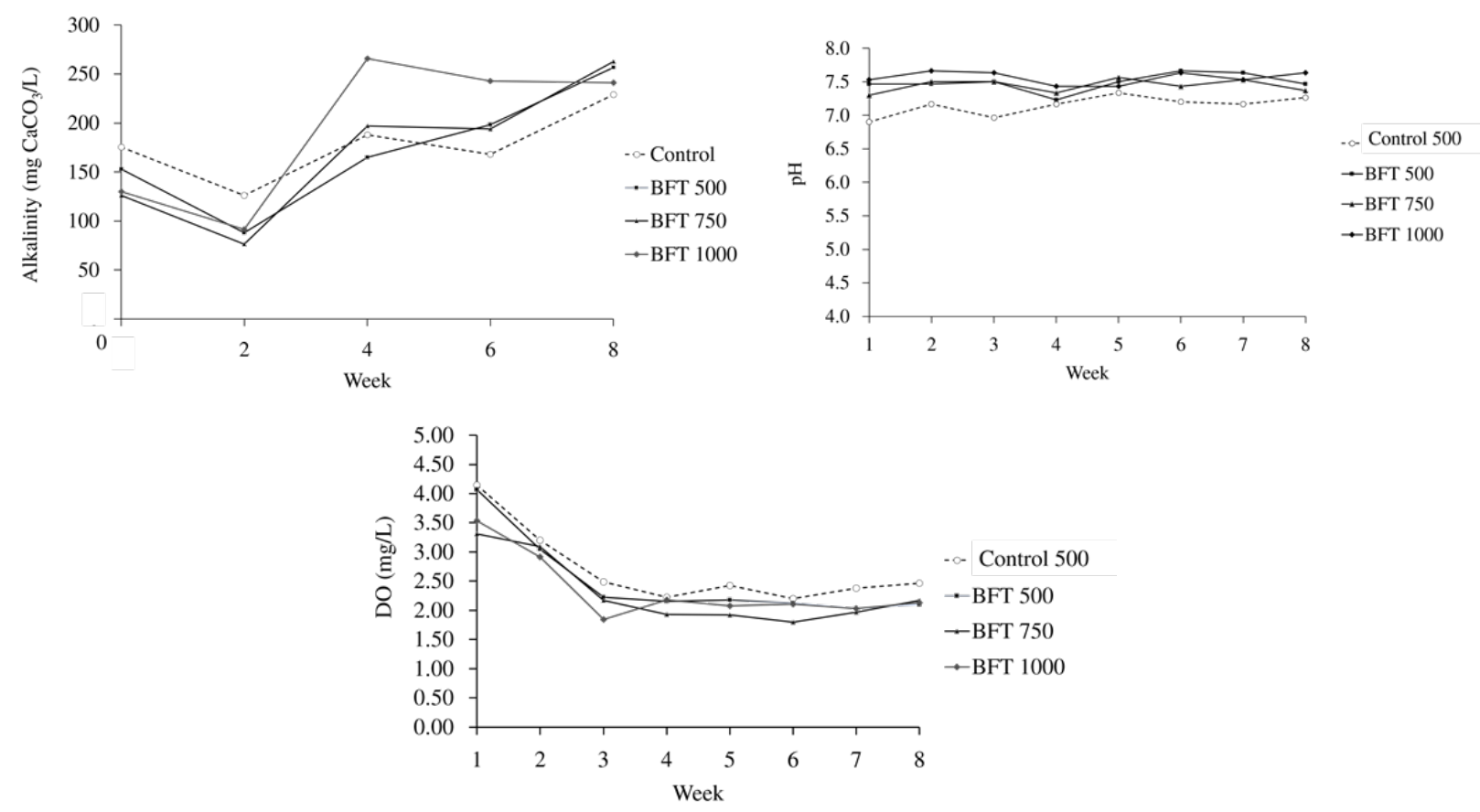

Figure 1. Weekly dissolved oxygen, alkalinity concentration and $\mathrm{pH}$ values in biofloc-based C. gariepinus culture at different densities $\left(500,750\right.$ and $\left.1000 \mathrm{fish} / \mathrm{m}^{3}\right)$ and a control during 8 weeks of culture period. 
the increase of the culture period. Furthermore, floc volume index in treatment BFT1000 showed the lowest value, which indicate that biofloc particles in this treatment was denserand has higher settleability than those of other biofloc treatments. This suggests that fish density, which affect the level of nutrient loading into the system, could affect biofloc physical characteristics.
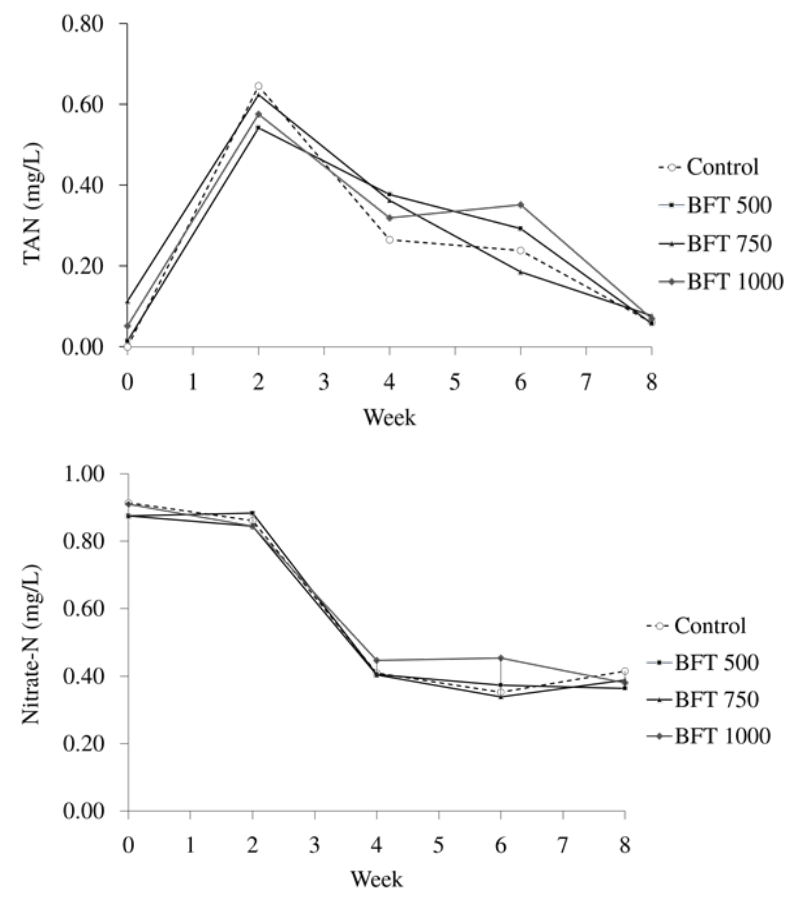

Lower survival was observed in biofloc systems with higher density (BFT750 and BFT1000), which may be attributed to the effect of overcrowding. Previous studies have been reported that overcrowding in aquaculture system could result in lower survival and growth and increase stress (Manley et al., 2014; Qun et
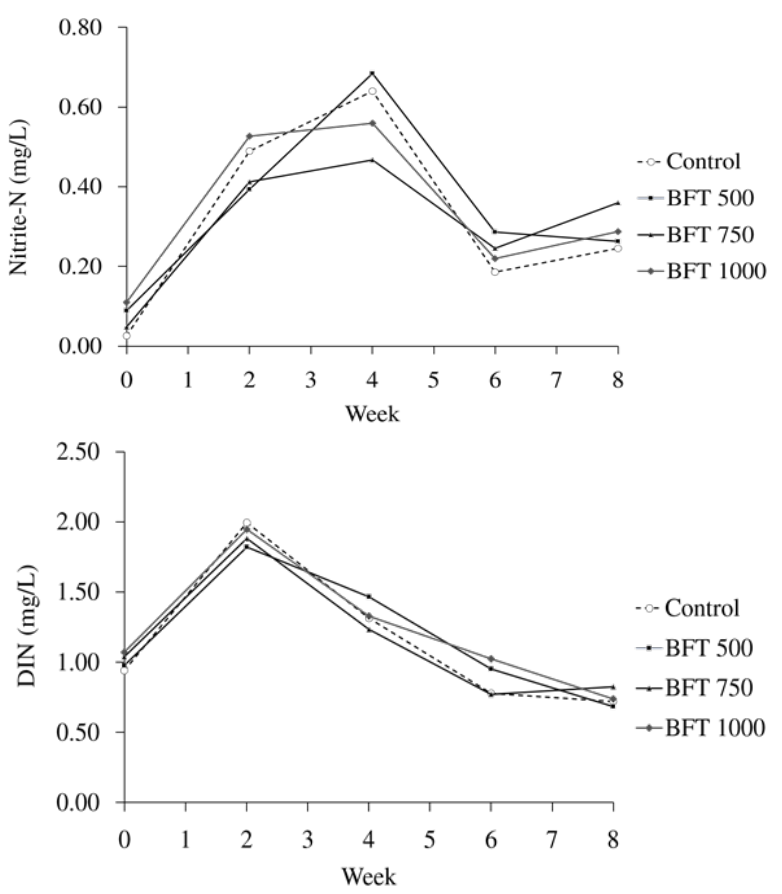

Figure 2. Total ammoniacal nitrogen (TAN), nitrite, nitrate, and dissolved inorganic nitrogen (DIN) concentrations in biofloc-based $C$. gariepinus culture at different densities $\left(500,750\right.$, and $1000 \mathrm{fish} / \mathrm{m}^{3}$ ) and the control during 8 weeks of culture period.
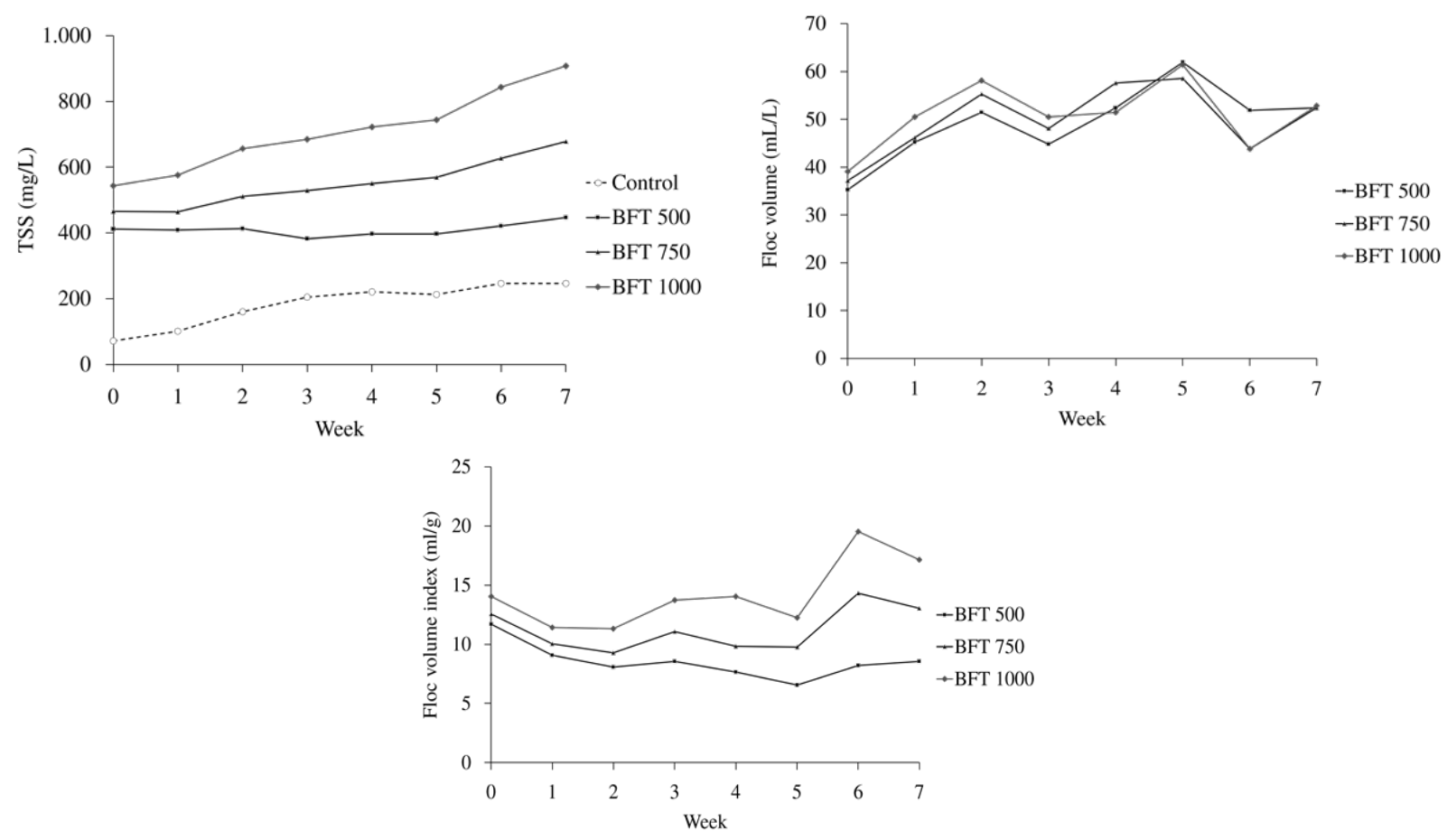

Figure 3. Total suspended solids (TSS), floc volume, and floc volume index in biofloc-based C. gariepinus culture at different densities $\left(500,750\right.$, and $\left.1000 \mathrm{fish} / \mathrm{m}^{3}\right)$ during 8 weeks of culture period. 
al., 2016). In African catfish culture, mortality might also be caused by cannibalistic behaviour in particular when the fish was varied in size (Biu et al., 2015; Rahmadiah et al., 2019). The fish growth in biofloc systems generally showed higher performance than that of the control, regardless the fish density. As the water quality was relatively similar between the treatments, the higher growth rate in the fish housed in biofloc systems may be related to the consumption of bioflocs as an additional live food for the fish. This result confirms previous studies that reported beneficial effects of biofloc systems on the growth of African catfish (Bakar et al., 2015; Romano et al., 2018; Chen et al., 2020). Although there were no significant differences in the FCR between all treatments, feed protein retention that represent protein utilization efficiency in biofloc treatments were about 50-60\% higher than that of the control. The higher growth rate in biofloc systems with high fish density seems compensate the higher mortality occurred in these treatments, thereby the fish biomass was still higher in higher fish density than that of the control. It is also important to point out that water utilization eficiency was significantly reduced in biofloc

Control 500

BFT 500
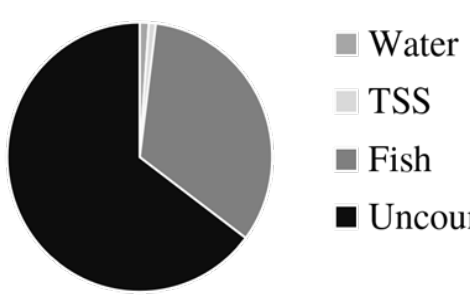

- Uncounted

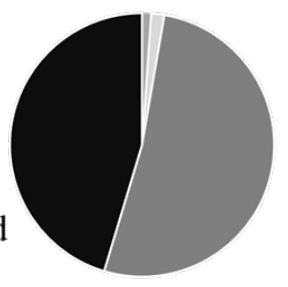

Water

I TSS

Fish

- Uncounted

BFT 750
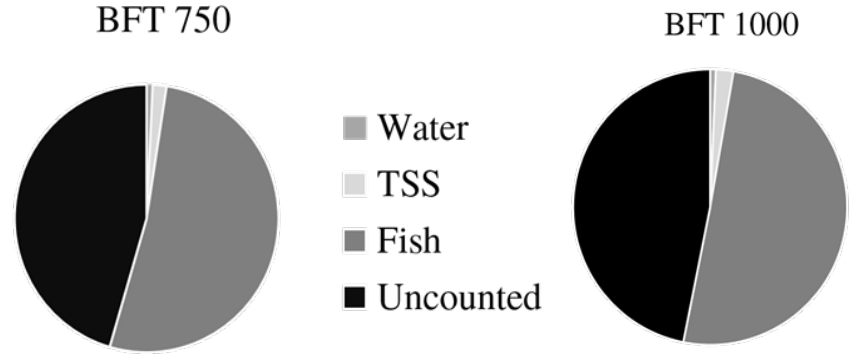

- Water

TSS

- Fish

- Uncounted

Figure 4. Nitrogen output distribution in biofloc-based C. gariepinus culture at different densities (500, 750, and $1000 \mathrm{fish} / \mathrm{m}^{3}$ ) and a control after 8 weeks of culture.
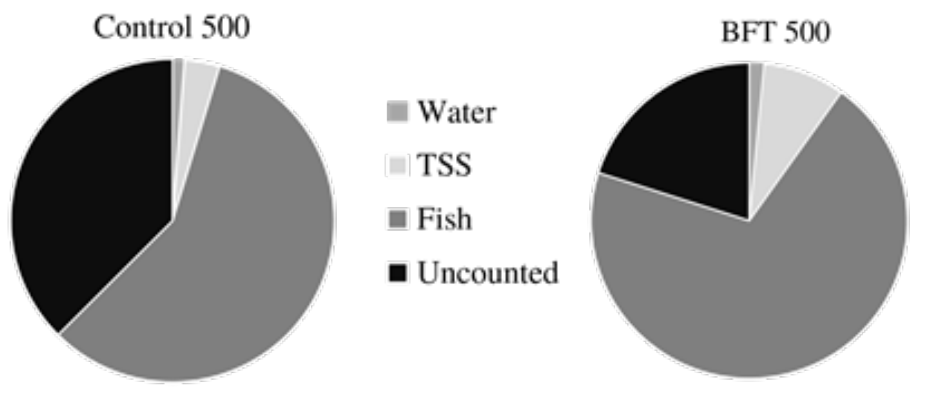

$$
\begin{aligned}
& \text { Water } \\
& \text { TSS } \\
& \text { - Fish } \\
& \text { - Uncounted }
\end{aligned}
$$

BFT 750

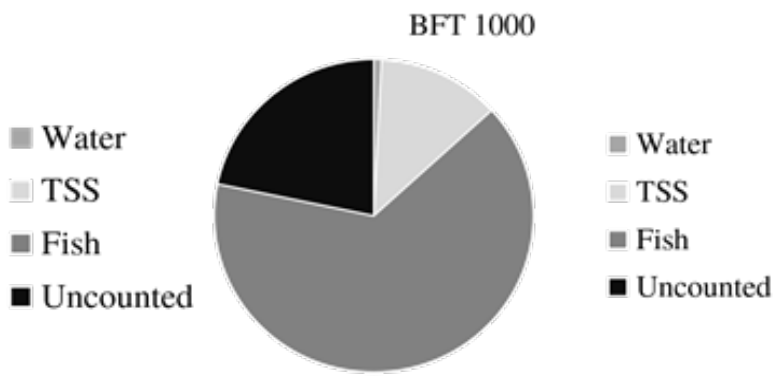

Figure 5. Phosphorus output distribution in biofloc-based $C$. gariepinus culture at different densities (500, 750, and $1000 \mathrm{fish} / \mathrm{m}^{3}$ ) and a control after 8 weeks of culture. 
systems (38-52\% lower) than that of the control, in particular at the treatments with higher density than 500 individuals $/ \mathrm{m}^{3}$.

The concentration of dissolved nitrogenous compounds in the water were relatively similar between the treatments. In biofloc systems, considerable amount of nitrogen was retained in the suspended solids, most likely in biofloc biomass. Unaccounted nitrogen may be attributed to the concentration of nitrogen gas generated by denitrification or anaerobic ammonia oxidation that was released into the air. Uncounted $\mathrm{N}$ in biofloc system was lower than that of the control at the same density. At higher fish density (750 and $1000 \mathrm{fish} / \mathrm{m}^{3}$ ), however, the quantity of uncounted $\mathrm{N}$ in biofloc systems were almost the same as in the control system with a density of $500 \mathrm{fish} / \mathrm{m}^{3}$, but in term of the proportion of the input, the percentage of uncounted $\mathrm{N}$ in bioflocs systems were lower than that of the control, regardless the fish density. Overall nitrogen utilization efficiency was higher in biofloc systems than that of the control. This may reflect the utilization of retained nitrogen in biofloc by the fish. This, however, still needs further confirmation. Different result was shown by Dauda et al. (2017) that show lower biofloc utilization by African catfish. Biofloc biomass appears to retain considerable amount of P. About 25-30\% of unutilized P was retained in bioflocs. This is also demonstrated by the lower level of uncounted $\mathrm{P}$ percentage in biofloc systems. Higher utilization efficiency of $\mathrm{P}$ in bioflocs systems may indicate better uptake and utilization of $\mathrm{P}$ in biofloc systems. Ekasari et al. (2019) reported that biofloc meal demonstrated considerably high P digestibility (88-94\%) in African catfish juvenile. The authors suggested that the presence of microbial phytase produced by the microbes associated in bioflocs may lead to the increase of $\mathrm{P}$ digestibility. Phosphorus utilization efficiency in African catfish in biofloc systems in the present study were within the range of that reported in previous study in recirculating aquaculture system (Strauch et al., 2018).

In conclusion the present study demonstrated that at the same density, the production performance between biofloc system and the control was not significantly different, however water and nitrogen utilizations were significantly more efficient in biofloc system than those of the control. As it was expected, fish density significantly affected the fish growth performance and productivity in biofloc systems, but not nitrogen and phosphorus utilization. Higher fish density significantly increased the productivity and water utilization efficiency, but reduced the fish survival and required more efforts to control biofloc biomass.

\section{ACKNOWLEDGEMENT}

The authors would like to thank to Mr. Ir. Hana Wijaya MM for facilitating the research to be conducted in his farm.

\section{REFERENCES}

AOAC. 1995. Official methods of analysis of AOAC International: Vol. I. Agricultural Chemicals; Contaminants, Drugs, $16^{\text {th }}$ ed. AOAC International, Arlington, VA.

APHA. 1998. Standard methods for the examination of the water and wastewater. American public health association. Washington DC.

Aubin J, Callier M, Rey-Valette H, Mathe S, Wilfart A, Legendre M, Slembrouck J, Caruso D, Chia E, Masson G, Blancheton JP, Ediwarman, Haryadi J, Prihadi TH, Casaca Jd M, Tamassia STJ, Tocqueville A, Fontane P. 2019. Implementing ecological intensification in fish farming: definition and principles from contrasting experiences. Reviews in Aquaculture 11: 149-167.

Avnimelech Y. 1999. Carbon/nitrogen ratio as a control element in aquaculture systems. Aquaculture 176: 227-235.

Bakar NSA, Nasir NM, Lananan F, Hamid SHA, Lam SS, Jusoh A. 2015. Optimization of C/N ratios for nutrient removal in aquaculture system culturing African catfish, Clarias gariepinus utilizing bioflocs technology. International Biodeterioration \& Biodegradation 102: 100106.

Biu AA, Mohammed GA, Yachilla BKM, Modu BM, Wakil UB, Mai AM, Benisheikh ABG, Adarju MB. 2015. Effects of sorting on cannibalism in catfish Clarias gariepinus rose in concrete tanks in Maiduguri, NorthEastern Nigeria. Animal and Veterinary Sciences 3: 67-73.

Bossier P, Ekasari J. 2017. Biofloc technology application in aquaculture to support sustainable development goals. Microbial Biotechnology 10: 1012-1016. 
Chen X, Luo G, Tan J, Tan H, Yao M. 2020. Effects of carbohydrate supply strategies and biofloc concentrations on the growth performance of African catfish Clarias gariepinus cultured in biofloc systems. Aquaculture 517: 734808.

Crab R, Defoirdt T, Bossier P, Verstraete W. 2012. Biofloc technology in aquaculture: beneficial effects and future challenges. Aquaculture 356: 351-356.

Dauda AB, Romano N, Ebrahimi M, The JC, Ajadi A, Chong CM, Karim M, Natrah I, Kamarudin MS. 2017. Influence of carbon/ nitrogen ratios on biofloc production and biochemical composition and subsequent effects on the growth, physiological status and disease resistance of African catfish Clarias gariepinus cultured in glycerol-based biofloc systems. Aquaculture 483: 120-130.

Dauda AB, Ajadi A, Adenike Susan Tola-Fabunmi AS, Ayoola Olusegun Akinwole AO. 2019. Waste production in aquaculture: Sources, components and managements in different culture systems. Aquaculture and Fisheries 4: 81-88.

De Schryver P, Crab R, Defoirdt T, Boon N, Verstraete W. 2008. The basic of bio-flocs technology: The added value for aquaculture. Aquaculture 277: 125-127.

Diana JS, Egna HS, Chopin T, Peterson MS, Cao L, Pomeroy R, Verdegem M, Slack WT, Bondad-Reantaso MG, Cabello F. 2013. Responsible aquaculture in 2050: valuing local conditions and human innovations will be key to success. BioScience 63: 255-262.

Ekasari J, Setiawati R, Ritonga FR, Setiawati M, Suprayudi MA. 2019. Growth and health performance of African catfish Clarias gariepinus (Burchell 1822) juvenile fed with graded levels of biofloc meal. Aquaculture Research 50: 1802-1811.

Emerenciano M, Gaxiola G, Cuzon G. 2013. Biofloc technology (BFT): a review for aquaculture application and animal food industry. In: Biomass Now - Cultivation and Utilization pp 1-28. INTECH. https://doi. org/10.5772/53902

Fauji H, Budiardi T, Ekasari J. 2018. Growth performance and robustness of African catfish Clarias gariepinus (Burchell) in biofloc-based nursery production with different stocking densities. Aquaculture Research 49: 13391346.
Fourooghifard H, Matinfar A, Mortazavi MS, Roohani GK, Mirbakhsh M. 2018. Nitrogen and phosphorous budgets for integrated culture of whiteleg shrimp Litopenaeus vannamei with red seaweed Gracilaria corticata in zero water exchange system. Iranian Journal of Fisheries Sciences 17: 471-486.

Germán CM, Jorge CM, Jennifer RN, Andrés ECC. 2018. Zooplankton growth in a biofloc system with different carbon sources in a Cyprinus carpio culture. International Journal of Fisheries and Aquatic Studies 6: 253-258

Herath SS, Satoh S. 2015. Environmental impact of phosphorus and nitrogen from aquaculture. In : Davis DA. Feed and Feeding Practices in Aquaculture. Woodhead Publishing, Cambridge. pp. 369-386.

Hostins B, Lara G, Decamp O, Cesar DE, Wasielesky Jr W. 2017. Efficacy and variations in bacterial density in the gut of Litopenaeus vannamei reared in a BFT system and in clear water supplemented with a commercial probiotic mixture. Aquaculture 480: 58-64.

Huisman EA. 1987. Principles of Fish Production. Department of Fish Culture and Fisheries, Wageningen Agriculture University. p 1-170.

Li M, Zhang M, Qian Y, Shi G, Wang R. 2020. Ammonia toxicity in the yellow catfish Pelteobagrus fulvidraco: The mechanistic insight from physiological detoxification to poisoning. Fish and Shellfish Immunology 102: 195-202.

Kjelland ME, Woodley CM, Swannack TM, Smith DL. 2015. A review of the potential effects of suspended sediment on fishes: potential dredging-related physiological, behavioral, and transgenerational implications. Environment Systems and Decisions 35: 334350.

Little DC, Bunting SW. 2016. Aquaculture technologies for food security. In Emerging Technologies for Promoting Food Security. Woodhead Publishing, Cambridge, pp 93-113.

Manley CB, Rakocinski CF, Lee PG, Blaylock RB. 2014. Stocking density effect on aggressive and cannibalistic behaviors in larval hatcheryreared spotted seatrout Cynoscion nebulosus. Aquaculture 420-421: 89-94.

Monroy-Dosta MC, Rodríguez-Montes de Oca G, Castro Mejia J, Becerril-Cortés D. 2015. Importance and function of microbial 
communities in aquaculture systems with no water exchange. Scientific Journal of Science 4: 103-110.

Nikolai SJ Dzialowski AR. 2014.Effects of internal phosphorus loading on nutrient limitation in a eutrophic reservoir. Limnologica 49: 33-41.

Palm HW, Knaus U, Wasenitz B, Bischoff AA, Strauch SM. 2018. Proportional up scaling of African catfish Clarias gariepinus Burchell, 1822 commercial recirculating aquaculture systems disproportionally affects nutrient dynamics. Aquaculture 491: 155-168.

Poli MA, Schveitzer R, Nuner APO. 2015. The use of ${ }^{\sim}$ biofloc technology in a South American catfish Rhamdia quelen hatchery: effect of suspended solids in the performance of larvae. Aquacultural Engineering 66: 17-21.

Qun L, Zhishuai H, Haishen W, Jifang L, Feng H, Jinhuan W, Qinglong W. 2016. Effect of stocking density on water quality and (growth, body composition and plasma cortisol content) performance of pen-reared rainbow trout Oncorhynchus mykiss. Journal of Ocean University of China 15: 667-675.

Rahmadiah T, Zairin M Jr, Alimuddin, Diatin I. 2019. Aggressive and cannibalistic behavior of African catfih larvae: effct of diffrent doses of methyltestosteron injecting to female broodstock and larval stocking densities. JurnalAkuakultur Indonesia 18: 182-192.

Rajta A, Bhatia R, Setia H, Pathania P. 2019. Role of heterotrophic aerobic denitrifying bacteria in nitrate removal from wastewater. Journal of Applied Microbiology 128: 1261-1278.
Rijn JV. 2013. Waste treatment in recirculating aquaculture systems. Aquacultural Engineering 53: 49-56.

Romano N, Dauda AB, Ikhsan N, Karim M, Kamarudin MS. 2018. Fermenting rice bran as a carbon source for biofloc technology improved the water quality, growth, feeding efficiencies, and biochemical composition of African catfish Clarias gariepinus juveniles. Aquaculture Research 49: 36913701.

Strauch S, Wenzel L, Bischoff A, Dellwig O, Klein J, Schüch A, Wasenitz B, Palm H. 2018. Commercial African catfish Clarias gariepinus recirculating aquaculture systems: assessment of element and energy pathways with special focus on the phosphorus cycle. Sustainability 10: 1805.

Wang HJ, Xiao XC, Wang HZ, Li Y, Yu Q, Liang XM, Feng WS, Shao JC, Rybicki M, Jungmann D, Jeppesen E. 2017. Effects of high ammonia concentrations on three cyprinid fish: Acute and whole-ecosystem chronic tests. Science of the Total Environment 598: 900-909.

Watanabe T. 1988. Fish nutrition and mariculture. JICA textbook The General Aquaculture Course. Tokyo: Kanagawa International Fish Training Center.

Zhang L, Xiong DM, Li B, Zhao ZG, Fang W, Yang K, Fan QX. 2012. Toxicity of ammonia and nitrite to yellow catfish Pelteobagrus fulvidraco. Journal of Applied Ichthyology 28: 82-86. 